\title{
Jesus is ook nou by sy kerk
}

\section{Book Title:}

Waar is Jesus nou?

\section{Book Cover:}

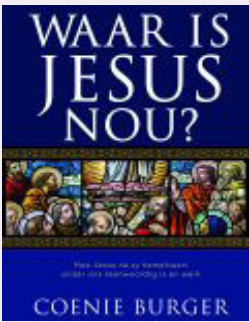

Author:

C. Burger

ISBN:

978-1-77000-979-0

Publisher:

CUM, 2011, R89.95*

*Book price at time of review

Review Title:

Jesus is ook nou by sy kerk

Reviewer:

Francois P. Viljoen

Affiliation:

${ }^{1}$ Faculty of Theology, North-West University,

Potchefstroom Campus,

South Africa

Email:

viljoen.francois@nwu.ac.za

Postal address:

Van Graanstraat 32,

Potchefstroom 2531,

South Africa

How to cite this book review: Viljoen, F.P., 2012, 'Jesus is ook nou by sy kerk', In die Skriflig/In Luce Verbi 46(1), Art. \#654, 1 page. http// dx.doi.org/ 10.4102/ids. v46i1. 654
Met die publikasie Waar is Jesus nou? bespreek Coenie Burger die betekenis van die hemelvaart van Jesus en die implikasies daarvan. Hy is van mening dat die kerk te min maak van hemelvaart en dat dit negatiewe gevolge vir die kerk en haar dienswerk op aarde inhou. Hy bespreek 'n aantal moontlike redes vir hierdie verwaarlosing en gepaardgaande misverstande. Hy pleit om 'n terugkeer na die Nuwe Testament en die belydenis van die vroeë kerk om die betekenis van Jesus se hemelvaart reg te verstaan. Hy bied perspektiewe om dit beter te begryp en vir die kerk om haar roeping in die tyd tussen die hemelvaart en wederkoms uit te leef. Hy bespreek hierdie onderwerp in vier dele.

In die eerste deel, 'Waar is Jesus nou? Ons verleentheid met die hemelvaart', verduidelik hy dat Jesus steeds by sy kerk is. Die mens moet nie leef asof Hy ver of afwesig is nie. 'n Wolk het Hom weggeneem en Hy sit nou aan die regterhand van die Vader. Nogtans bly Jesus daagliks betrokke by wat in die kerk en in die breër lewe op aarde gebeur.

In deel twee, 'Hoe Jesus ná sy hemelvaart by ons teenwoordig is en onder ons werk', verduidelik hy Jesus se optrede as Koning, Priester en Profeet. Jesus werk daagliks onder ons as sagmoedige Koning. As Hoëpriester hou Hy ons vas en tree Hy vir ons by God in. As Profeet roep Hy ons tot dissipelskap en leer en lei Hy ons.

In die derde deel, 'Hoe Jesus deur sy hemelvaart ruimte maak vir die sy kerk om in sy werk te deel', verduidelik Burger hoe Jesus gelowiges toerus om sy werk op aarde voort te sit. Jesus skakel gelowiges by sy werk in. Deur sy Gees rus Hy hulle met krag uit die hoogte toe vir hulle werk. Hy versamel sy kerk om sy liggaam op aarde te wees en sy beeld uit te dra.

In deel vier, 'Wat die Here van ons vra ... om profete, priesters en koningskinders te wees', bespreek hy die roeping van gelowiges op aarde. Die Heilige Gees maak van hulle profete wat in Jesus glo en van Hom getuig. Die Gees maak van hulle priesters wat soos Jesus omgee, liefhet en dien. Die Heilige Gees maak van hulle koningskinders wat op God hoop en Hom gehoorsaam.

In 'n wêreld waar baie mense leef asof God afwesig is en die kerk in haar roeping verflou, dien hierdie publikasie om lesers te herinner aan die basiese waarhede oor die feit en betekenis van Jesus se hemelvaart. Gelowiges word getroos en opnuut opgeroep om bewustelik in die teenwoordigheid van die verhoogde Here Jesus Christus te leef en met geloofsvertroue hulle taak op aarde te vervul.

Gelowiges wat opnuut verseker wil word van Jesus se heerskappy en daaglikse betrokkenheid in hulle lewe, asook opgeskerp wil word oor hul opdrag as gelowiges in die wêreld, behoort by hierdie publikasie te baat. Basiese en tradisionele geloofswaarhede word op 'n eenvoudige manier vir die leser aangebied. Die publikasie bied egter nie nuwe insigte oor die tema nie. Interaksie met die hedendaagse teologiese gesprekke oor die die onderwerp ontbreek. Die publikasie dien as stigtelike lektuur, maar bied nie werklik 'n nuwe teologiese bydrae nie. 